\title{
Influence of selected fungicides and hormone on the rooting success of Shea (Vitellaria paradoxa gaernt) stem cuttings
}

\author{
Yeboah, J., Akrofi, A. Y. and Owusu-Ansah, F \\ Cocoa Research Institute of Ghana, Box 8, Tafo-Akim, Ghana
}

\begin{abstract}
The sheanut tree (Vitellaria paradoxa Gaertn) is indigenous to the Guinea Savanna belt of West Africa extending from Senegal in the West to Sudan in the East. The tree's response to vegetative propagation methods is very poor and inconsistent. Impact of different fungicides (Ridomil 72 plus, Dithane M45, Nordox 75 and Kocide 101), their different concentrations and frequencies of application and the application of a hormonal rooting powder (Seradix 3 ) were studied at Bole, Ghana from June to August, 2005. Significant rooting was observed when Dithane M45 was applied at 2000ppm three times (once every two weeks) during the rooting period and gave the highest rooting performance when combined with Seradix 3 hormone. High concentrations of Dithane M45 did not significantly affect the degree of infection on cuttings. However, cuttings which were not sprayed with any fungicide recorded significantly $(P<0.05)$ high fungal infection. Ridomil 72 Plus, Kocide 101and Nordox 75 lower rooting performance in shea cuttings.
\end{abstract}

Keyword: Influence, Fungicide, Hormones, Sheanut tree Vitellaria paradoxa, rooting, Ghana

\section{INTRODUCTION}

Sheanut tree (Vitellaria paradoxa Gaertn) is one of the more frequently found species in the Guinea Savanna belt of West Africa extending from Senegal in the West to Sudan in the East (Dalziel, 1955). It is recognized as a non-traditional export crop. Processed shea butter is known to have very good qualities and could act as a possible substitute for cocoa butter for manufacturing cosmetic products (Hall et al., 1996). It is appreciated for its skin healing and protective properties (Michael and Koffi, 2001). In Northern Ghana, the sheanut tree is the main source of livelihood to a large number of the populace (Irvine, 1961). Due to its importance to the inhabitants of the Northern part of Ghana, traditional laws have been enacted which make it a taboo to cut down the tree under any circumstance (Bolewura Amankwaa, personal communication).

Opoku-Ameyaw et al. (1996), working at Cocoa Research Institute of Ghana (CRIG) substation at Bole achieved little success using air layering with softwood (33.3\%) and semi-hardwood (22.3\%). Other trials performed at the same location showed that stem cuttings from coppiced sheanut trees had promising rooting ability (Opoku-Ameyaw et al., 2000). Currently, the development of effective propagation method that will facilitate the rapid multiplication of trees to meet increasing demand for planting materials is the main focus of CRIG's research activity. Vegetative propagation methods vary with genetic constitution of the plant species
(Nanda and Tandon, 1967), but success rate of most vegetative methods (grafting, budding, layering and cuttings) is low (Opoku-Ameyaw et al., 2000) and according to Hartmann et al., (1997), this may be improved by considering essential environmental and biochemical factors .

A major cause for low success of vegetative propagation methods in shea is poor rooting of cuttings and this has hampered the establishment of shea plantations in Ghana. Most of the cuttings suffer from fungal attack during the rooting process thus hampering rooting performance (personal observation). This paper reports on experiments conducted at the Cocoa Research Institute of Ghana substation at Bole in the Northern Ghana to establish reasons for the low and inconsistent propagation successes and to develop strategies to ensure successful propagation techniques which will facilitate rooting of cuttings of the sheanut tree.

\section{MATERIALS AND METHODS}

Study Site: A series of experiments were carried out at the Cocoa Research Institute's substation at Bole in the Northern Region of Ghana in 2005. Bole is located within an altitudinal range of $100-600 \mathrm{~m}$ with one rainfall maxima $(600-1400 \mathrm{~mm})$ which occurs from May to September (Hall et al., 1996) and mean annual temperatures ranging from 25 to $29^{\circ} \mathrm{C}$. The Northern Region falls within Guinea Savanna belt of West Africa. 
Experiments were carried out in a polythene propagator made of a wooden frame and covered with a transparent polythene sheet. The propagator, divided into apartments of $1.96 \mathrm{~m}^{2}$ each was filled with layers of stones, gravels and sterilized rice husk rooting medium (Yeboah, 2005; Ofori-Gyamfi,1998)
(Figure 1). Unless otherwise stated, the base of each shea cutting was dipped into 8000ppm Seradix 3 hormone (indolebutyricacid, indoleaceticacid and cytokinins) to a depth of $0.05 \mathrm{~m}$ for five seconds, airdried for $10 \mathrm{sec}$ and inserted into the rooting medium. Spacing between the cuttings was $0.13 \mathrm{~m}$.

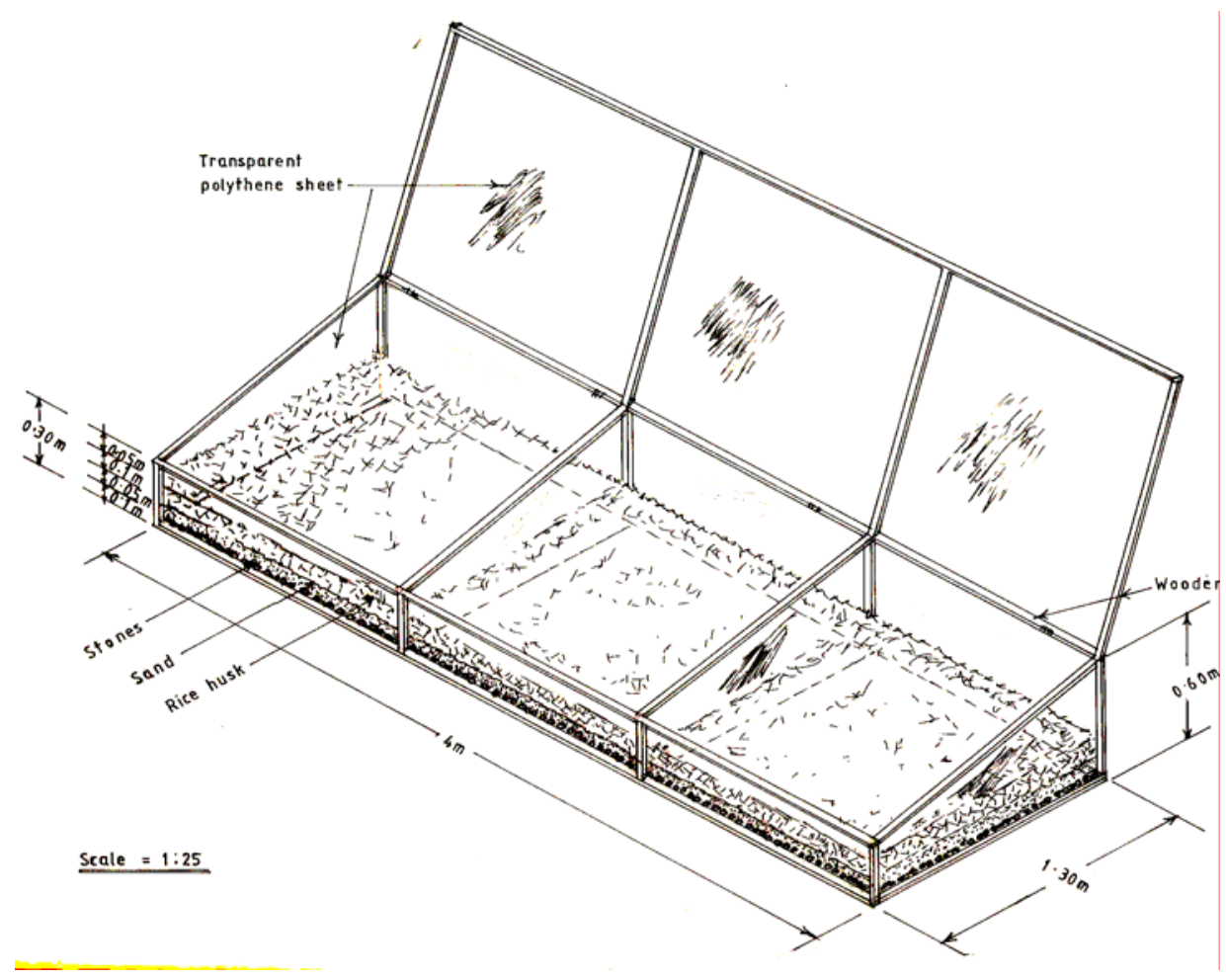

Fig 1: The polythene propagator used in the experiments showing arrangements of stones, gravels and growing medium.

Effects of fungicides and Seradix 3 hormone on rooting of shea stem cuttings: In this experiment, four types of fungicides, Dithane M45 (16\% zinc; $3 \%$ manganese and ethylene), Ridomil 72 Plus (60\% copper oxide; $12 \%$ metalaxyl), Nordox 75 (75\% cuprous oxide) and Kocide 101 (77\% copper hydroxide) and Seradix 3 hormone were assessed in a two factor factorial experiment in the randomized complete block design in July, 2004. Factor A was five different fungicides, whiles factor $B$ was hormone. Two hundred coppiced (rejuvenated shoots) cuttings were prepared by retaining 6 leaves on it as recommended by Opoku-Ameyaw et al. (2000). The cuttings were divided into two batches of 100 each. The first batch was sub-divided into 5 sets of 20 cuttings each. Each set was placed in a separate apartment of the propagator and later sprayed with any of the four fungicides for 2 minutes at the manufacturer's recommended concentration. Dithane M45 was sprayed at 3000ppm, Ridomil 72 plus and Kocide 101 at 3300ppm and Nordox 75 at 3300ppm.

The second batch was also divided into 5 sets as above, dipped into Seradix 3 hormone before sprayed with the fungicides as was done for the first batch. Thus, the 10 treatment combinations assessed on the cuttings were:

1. without Seradix 3 hormone and fungicide,

2. sprayed with Dithane M45 alone

3. $\quad$ sprayed with Ridomil 72 plus alone

4. sprayed with Nordox 75 alone

5. sprayed with Kocide 101 alone

6. treated with Seradix 3 alone

7. treated with Seradix 3 hormone and sprayed with Dithane M45

8. $\quad$ treated with Seradix 3 hormone and sprayed with Ridomil 72 plus

9. $\quad$ treated with Seradix 3 hormone and sprayed wth Nordox 75 
10. treated with Seradix 3 hormone and sprayed with Kocide 101

The experiment was repeated three times. Monitoring was done weekly to remove dead and infected leaves and cuttings. Cuttings were weekly observed for signs of rooting from the $30^{\text {th }}$ to $120^{\text {th }}$ day. Rooting and number of roots developed, root length, callus formation, dormancy, infection on leaves and on cuttings were recorded.

Effect of varying concentrations of Dithane M45 and Seradix 3 hormone on rooting of shea stems cuttings: Due to the promising performance of Dithane M45 in the earlier experiment, varying concentrations of Dithane M45 were further evaluated on the rooting performance of shea cuttings. A set of 160 cuttings, each $1.5 \mathrm{~cm}$ long, were prepared by retaining 6 leaves per cutting (Ameyaw et al., 2000). The design was a two factor factorial in the randomized complete block design. Dithane M45 was tested at 0, 2000, 3000 and 4000ppm and Seradix 3 hormone at 0 ppm and 8000 $\mathrm{ppm}$. The 160 cuttings were divided into two batches of 80 each. One batch was further divided into four groups of 20 and each of the 20 cuttings in a group placed in one apartment of the propagator. The cuttings in each apartment were sprayed with one of the four Dithane M45 concentrations for 2 minutes with a hand sprayer. The other batch of 80 cuttings was first dipped in Seradix 3 hormone, subdivided into four groups as above and set in a second propagator. Each group was sprayed with one of the Dithane M45 concentrations for the same duration of 2 min. Each treatment was replicated three times. Monitoring was done weekly to remove dead and infected leaves and cuttings. Cuttings were weekly observed for signs of rooting from the $30^{\text {th }}$ to 120 th days after setting. Rooting and number of roots developed, root length, callus formation, dormancy, infection on leaves and on cuttings were recorded

Frequency of application of Dithane M45 and Seradix 3 hormone application on rooting of coppiced shea cuttings: Results of the effect of Dithane M45 and Seradix 3 hormone on rooting experiment indicated that Dithane M45 at 2000ppm gave the best rooting. An experiment was therefore conducted to determine the frequency of application of Dithane M45 and Seradix 3 hormone which will give optimum rooting success in shea. Dithane M45 was sprayed at 2000ppm on the stem cuttings once, two, three or four times and combined with 0ppm or 8000ppm Seradix 3 hormone in a $4 \times 2$ factorial in a randomized complete block design. A set of 160 coppiced shea stem cuttings were prepared as above, divided into two batches of 80 each. The first batch of cuttings was dipped in Seradix 3 hormone and set in the propagator with 20 cuttings in each apartment and sprayed at two weekly intervals for eight weeks with Dithane M45 at 2000ppm such that treatment 1, 2, 3 and 4 received one, two, three and four sprays respectively. Cuttings in the other batch were not dipped in Seradix 3 hormone but the same sequence of fungicide spraying described earlier was followed. The experiment was replicated three times. Monitoring was done weekly to remove dead and infected leaves and cuttings. Cuttings were weekly observed for signs of rooting from the $30^{\text {th }}$ to 120th day after setting. Rooting and number of roots developed, root length, callus formation, dormancy, infection on leaves and on cuttings were recorded.

\section{RESULTS AND DISCUSSION}

The effects of different types of fungicide and Seradix 3 hormone and their interaction on the rooting of shea stem cuttings are shown in Table 1. Significant $(P<0.05)$ number of roots developed on cuttings for all the fungicides at 3000ppm with Dithane M45 recording more roots than the other fungicides. The control gave the lowest rooting success. Callus formation was better and also significant for the tested fungicides than the untreated control. No significant effects were observed for dormancy in the cuttings and the number of roots per cutting. Dithane M45 treated cuttings recorded longer roots but did not significantly differ from the other fungicides. However the cuttings which were not sprayed with any fungicide developed the shortest roots.

The higher success in rooting obtained for the Dithane M45 treatment may be attributed to the presence of manganese $(\mathrm{Mn})$ and zinc $(\mathrm{Zn})$ which are the main elements required to enhance root formation. According to Jarvis (1986), $\mathrm{Mn}$ is responsible for activating the enzyme indoleaceticacid oxidase (IAA-oxidase) in cell division and rooting while $\mathrm{Zn}$ liberates IAA through the biosynthesis of tryptophan (Leopold, 1960). Unlike Dithane M45, the other fungicides contained copper. Copper is reported to inhibit rooting by reducing apical meristematic activity which results in the dropping of leaves, resulting in the poor rooting performance (Landis et al., 1990). Many injurious effects of copper based fungicides on leaf and stem have been reported, particularly in apples and pears (Hartmann et al., 1997; Llewelyn 1957). 
Agric. Biol. J. N. Am., 2010, 1(3): 313-320

Table 1: Effects of types of Fungicide and Seradix 3 hormone and their_interaction on the rooting of shea stem cuttings.

\begin{tabular}{|c|c|c|c|c|c|}
\hline \multirow{2}{*}{ Fungicides } & \multicolumn{3}{|c|}{ Percentage of cuttings that survived } & \multirow{2}{*}{$\begin{array}{l}\text { Mean no. } \\
\text { of roots } \\
\text { per cutting }\end{array}$} & \multirow{2}{*}{$\begin{array}{l}\text { Mean root } \\
\text { length }(\mathrm{cm})\end{array}$} \\
\hline & Rooted & Callus & Dormancy & & \\
\hline Control (No Fungicide) & $2.0(4.7)$ & $0.0(0.6)$ & $1.5(1.8)$ & 1.2 & 0.1 \\
\hline Dithane M 45 & $65.0(55.4)$ & $20.0(19.7)$ & $5.0(7.9)$ & 1.5 & 9.63 \\
\hline Ridomil 72 Plus & $35.0(35.0)$ & $35.0(31.0)$ & $5.0(6.1)$ & 2.5 & 9.40 \\
\hline Kocide 101 & $30.0(32.1)$ & $35.0(32.5)$ & $5.0(9.5)$ & 1.3 & 7.02 \\
\hline Nordox 75 & $45.0(41.7)$ & $30.0(28.2)$ & $10.0(11.4)$ & 1.3 & 9.50 \\
\hline $\operatorname{LSD}(P=0.05)$ & $(14.6)$ & $(22.5)$ & (ns) & ns & 4.766 \\
\hline \multicolumn{6}{|l|}{ Seradix 3 Hormone } \\
\hline Control (No Seradix 3 horm.) & $27.0(28.0)$ & $26.0(24.6)$ & $2.5(3.3)$ & 1.8 & 5.76 \\
\hline Seradix 3 hormone & $44.3(39.5)$ & $22.0(21.3)$ & $8.5(13.1)$ & 1.33 & 8.31 \\
\hline $\operatorname{LSD}(P=0.05)$ & (9.4) & (ns) & (11.61) & $\mathrm{ns}$ & ns \\
\hline \multicolumn{6}{|l|}{ Fungicide / Seradix 3 Horm. } \\
\hline No fungicide $\times$ Control & $2.0(4.7)$ & $0.0(0.6)$ & $0.5(2.3)$ & 1.3 & 0.1 \\
\hline Dithane M45 x Control & $40.0(39.1)$ & $40.0(38.9)$ & $0.0(0.6)$ & 1.3 & 4.67 \\
\hline Ridomil 72 Plus $\times$ Control & $20.0(25.4)$ & $20.0(17.3)$ & $10.0(11.5)$ & 4.0 & 11.1 \\
\hline Kocide 101 x Control & $30.0(32.3)$ & $30.0(31.2)$ & $0.0(0.6)$ & 1.3 & 6.0 \\
\hline Nordox $75 \times$ Control & $40.0(38.4)$ & $40.0(35.1)$ & $0.0(0.6)$ & 1.0 & 7.0 \\
\hline No fungicide $\times$ Seradix 3 & $1.7(4.7)$ & $0.0(0.6)$ & $3.0(9.3)$ & 1.0 & 0.1 \\
\hline Dithane M45 x Seradix 3 & $90.0(71.6)$ & $0.0(0.6)$ & $10.0(15.2)$ & 3.8 & 13.8 \\
\hline Ridomil 72 Plus $x$ Seradix 3 & $50.0(44.7)$ & $50.0(44.7)$ & $0.0(0.6)$ & 1.0 & 7.7 \\
\hline Kocide $101 \times$ Seradix 3 & $30.0(31.9)$ & $40.0(31.9)$ & $10.0(18.4)$ & 1.3 & 8.03 \\
\hline Nordox $75 \times$ Seradix 3 & $50.0(45.0)$ & $20.0(21.4)$ & $20.0(22.1)$ & 1.67 & 12.0 \\
\hline Interaction LSD $(P=0.05)$ & $(21.01)$ & (ns) & (ns) & 2.2 & 6.5 \\
\hline
\end{tabular}

Applying Seradix 3 hormone at 8,000ppm did not significantly influence callus formation, number of roots per cutting and root length but significantly $(P<0.05)$ enhanced the number of rooted cuttings and dormancy (Table 1). The results showed that Seradix 3 hormone helped rooting in shea cuttings through its hormonal activity. Middleton et al. (1980) suggested that carbohydrate concentrations may be influenced by auxin which can also enhance mobilization of carbohydrates in leaves in the upper stem and increase transport to the rooting zone. The low rooting performance of the control treatment may be due to the absence of the hormone to boost the level of the endogenous IAA to promote rooting through cell division (Kozlowski and Kramer, 1979).

There were significant interaction effects among the treatments, except for callus formation and dormancy (Table 1).Thus, the use of fungicides and the hormone significantly $(P<0.05)$ affected the number of rooted cuttings, number of roots per cutting and root length. Cuttings sprayed with 3000ppm Dithane
M45 and dipped in 8000ppm Seradix 3 hormone recorded the highest and longest roots. Cuttings which were neither sprayed with fungicide nor dipped in hormone were inferior to both the fungicide alone and fungicide-hormone treatments. Seradix 3 hormone contains indolebutyricacid (IBA) which has been reported to increase the IAA levels thus enhancing cell division leading to rooting (Hartmann et al., 1997).

Table 2 shows that fungicide treatments gave significantly $(\mathrm{P}<0.05)$ more and longer roots, and dormant cuttings. Cuttings dipped in 2000ppm of Dithane M45 recorded the highest number and longest roots; while only $1 \%$ cuttings rooted in the nofungicide treatment (control). There was a reduction in the number of rooted cuttings as the concentration of Dithane M45 increased beyond 2000ppm. At 4000ppm, Dithane M45 recorded the highest number of callused and dormant cuttings. No significant effect was observed for the number of roots per cutting for the various concentrations of Dithane M45 tested. 
Jackson (1986) indicated that, high concentrations of plant substances can be toxic and inhibitory, and can adversely affect the rooting performance of cuttings (Moorman et al., 1983; Reuveni and Raviv, 1980). This probably accounted for the poor rooting performance of Dithane M45 at 3000 and 4000ppm and may be due to higher levels of $M n$ and $Z n$ which are inhibitory to the functioning of auxins for rooting.

Seradix 3 hormone gave significantly $(P<0.05)$ more rooting and dormant cuttings than the control, but did not significantly affect callus formation, number of roots per cutting and root length. Cuttings sprayed with 2000ppm Dithane M45 and dipped in Seradix 3 hormone significantly $(P<0.05)$ produced the highest number of rooted cuttings (mean of 11.5). Cuttings which were sprayed with 4000ppm Dithane M45 without hormone application significantly $(P<0.05)$ recorded the highest incidence of dormancy while those which were not sprayed with the fungicide but dipped in the hormone recorded low or no rooting.

Table 2: Effect of concentrations of Dithane M45 and Seradix 3 hormone and their interaction on the rooting of shea stems cuttings.

\begin{tabular}{|c|c|c|c|c|c|}
\hline \multirow[t]{2}{*}{ Concentrations of DithaneM45 } & \multicolumn{3}{|c|}{ Percentage of cuttings that survived } & \multirow{2}{*}{$\begin{array}{l}\text { Mean No. } \\
\text { of roots } \\
\text { per } \\
\text { cutting }\end{array}$} & \multirow{2}{*}{$\begin{array}{l}\text { Mean } \\
\text { root } \\
\text { length } \\
(\mathrm{cm})\end{array}$} \\
\hline & Rooted & Callused & Dormant & & \\
\hline Control (No DithaneM45) & $1.0(2.9)$ & $0.0(0.6)$ & $0.0(0.6)$ & 0.0 & 0.0 \\
\hline 2000ppm & $50.0(45.1)$ & $27.5(30.1)$ & $10.0(13.4)$ & 9.2 & 21.7 \\
\hline 3000ppm & $42.5(40.1)$ & $12.5(20.2)$ & $5.0(8.0)$ & 6.0 & 14.5 \\
\hline 4000ppm & $22.5(26.8)$ & $55.0(48.1)$ & $21.7(26.1)$ & 3.9 & 12.1 \\
\hline $\operatorname{LSD}(P=0.05)$ & $(11.2)$ & $(9.4)$ & $(11.0)$ & ns & 3.9 \\
\hline \multicolumn{6}{|l|}{ Seradix 3 Hormone } \\
\hline Control (No Seradix 3 horm.) & $16.5(21.0)$ & $29.5(28.1)$ & $14.6(18.1)$ & 4.6 & 12.2 \\
\hline Seradix 3 hormone & $41.0(36.4)$ & $18.5(21.4)$ & $3.8(6.0)$ & 5.3 & 12.0 \\
\hline $\operatorname{LSD}(P=0.05)$ & $(7.9)$ & (ns) & $(7.8)$ & ns & $3.9 \mathrm{~ns}$ \\
\hline \multicolumn{6}{|l|}{$\begin{array}{ll}\begin{array}{l}\text { Concentration } \\
\text { of Dithane M45 }\end{array} & \text { Seradix } \\
& 3 \text { hormone }\end{array}$} \\
\hline 0 ppm (fung.) $\times$ No hormone & $2.0(5.2)$ & $0.0(0.6)$ & $0.6(0.6)$ & 0.0 & 0.0 \\
\hline 2000ppm x No hormone & $25.0(29.2)$ & $45.0(42.1)$ & $20.0(26.1)$ & 6.8 & 22.6 \\
\hline 3000ppm x No hormone & $30.0(32.2)$ & $10.0(18.4)$ & $10.0(15.4)$ & 7.1 & 15.4 \\
\hline 4000ppm x No hormone & $10.0(17.5)$ & $60.0(52.1)$ & $30.0(30.1)$ & 4.3 & 10.6 \\
\hline No Dithane M45 x Seradix 3 & $0.0(0.6)$ & $0.0(0.6)$ & $0.0(0.6)$ & 0.0 & 0.0 \\
\hline 2000ppm x Seradix 3 horm. & $75.0(61.0)$ & $10.0(18.0)$ & $0.0(0.6)$ & 11.5 & 20.8 \\
\hline 3000ppm x Seradix 3 “ & $55.0(47.9)$ & $15.0(22.0)$ & $0.0(0.6)$ & 6.1 & 13.5 \\
\hline 4000ppm x Seradix 3 “ & $35.0(36.1)$ & $50.0(45.1)$ & $15.0(22.0)$ & 3.4 & 13.5 \\
\hline Interaction LSD $(P=0.05)$ & (15.8) & (13.3) & $(15.6)$ & 3.1 & 7.9 \\
\hline
\end{tabular}

Figures in parenthesis are angular transformed values ns- not significant

Significantly higher $(P<0.05)$ rooting occurred with the three times spraying of Dithane M45 at 2000ppm than the control treatment which recorded no rooting (Table 3). The three times application of the fungicide also recorded significantly $(P<0.05)$ higher number of dormant cuttings and longer roots than the other treatments. The rooting performance may be due to the fungicide which protected the leaves on the 
cuttings from infection (Reuveni and Raviv, 1981) resulting in the provision of photosynthates for the cuttings (Hartmann et al., 1997). The four times application, however, reduced the rooting performance. This result agrees with Jackson's (1980) who observed that high concentration of fungicide becomes inhibitory to the performance of auxin in cuttings. With the exception of the number of dormant cuttings which did not respond significantly to hormone application, cuttings which were dipped in Seradix 3 hormone significantly gave more and longer rooting, than the control (Table 3). As observed by Blazich et al. (1983), movement of boron, nitrogen, zinc and potassium to the rooting zone is enhanced by auxin treatment This phenomenon might have promoted a better rooting performance in the Seradix 3 hormone treated cuttings. The Seradix 3 hormone also enhanced the mobilization of carbohydrates in leaves, upper stem and increased transport to the rooting zone (Middleton et al., 1980).

Nordox 75 recorded the lowest infection rate. Also, the various concentrations of the fungicides gave no significant differences in the numbers of dead cuttings and leaves that dropped but were better than the control. Cuttings sprayed with Dithane M45 at $3000 p p m$ and $4000 p p m$ had low infection on both the stems and leaves. Spraying Dithane M45 at 2000ppm at the various frequencies (except control) significantly affected the degree of infection on the cuttings and leaves. Four times application recorded the lowest infection rate (Table 4). Hartmann et al. (1997) observed that infection occurs on materials which are not treated with fungicide and can destroy both the leaves and the stem. This was supported by Yoder (1980) and Otani et al. (1985) who further explained that, the presence of fungi on cuttings resulted in the release of some toxic substances that penetrated and destroyed the tissues in the cuttings. Fungicides sprayed on plants helped in the retention of leaves (Ruveni and Raviv, 1981) and enhanced photosynthetic activity as well as the production some plant substances such as vitamins, phenols and auxins which contributed to their growth and development (Leopold, 1960).

Table 3: Effects of frequency of application of Dithane M45 and Seradix 3 hormone and their interaction on the rooting of shea stem cuttings.

\begin{tabular}{|c|c|c|c|c|c|}
\hline \multirow[b]{2}{*}{ Fequency of spraying Dithane M45 } & \multicolumn{3}{|c|}{ Percentage of cuttings Alive } & \multirow{2}{*}{$\begin{array}{l}\text { Mean No. } \\
\text { of roots } \\
\text { per cutting }\end{array}$} & \multirow{2}{*}{$\begin{array}{l}\text { Mean root } \\
\text { length (cm } \\
\text { ) }\end{array}$} \\
\hline & Rooted & Callus & Dormant & & \\
\hline Control (No DithaneM45) & $0.0(0.6)$ & $0.0(0.6)$ & $0.0(0.6)$ & 0.0 & 0.0 \\
\hline Once & $25.0(29.2)$ & $25.0(27.2)$ & $10.0(13.6)$ & 3.0 & 3.2 \\
\hline Twice & $35.0(35.8)$ & $35.0(35.0)$ & $25.0(29.5)$ & 3.2 & 11.5 \\
\hline Thrice times & $50.0(44.5)$ & $10.0(13.0)$ & $40.0(38.3)$ & 3.3 & 10.9 \\
\hline Four times & $40.0(39.0)$ & $30.0(30.7)$ & $25.0(27.8)$ & 1.6 & 8.3 \\
\hline LSD $(P=0.05)$ & (11.1) & (ns) & $(10.3)$ & 4.5 & 1.6 \\
\hline \multicolumn{6}{|l|}{ Seradix 3 Hormone } \\
\hline Control (No Seradix 3 horm.) & $24.0(26.1)$ & $23.0(23.2)$ & $22.0(22.4)$ & 1.4 & 5.2 \\
\hline Seradix 3 hormone & $36.0(33.6)$ & $18.0(19.6)$ & $18.0(19.5)$ & 4.3 & 8.3 \\
\hline LSD $(P=0.05)$ & $(7.0)$ & $(11.4)$ & (ns) & 1.0 & 2.8 \\
\hline \multicolumn{6}{|l|}{$\begin{array}{l}\text { Frequency of I Seradix } 3 \\
\text { Spraying Hormone Dithane M45 }\end{array}$} \\
\hline No Dithane M45 x No Seradix 3 & $0.0(0.6)$ & $0.0(0.6)$ & $0.0(0.6)$ & 0.0 & 0.0 \\
\hline Once DithaneM45 & $30.0(32.3)$ & $30.0(32.3)$ & $20.0(26.6)$ & 2.3 & 2.4 \\
\hline Twice DithaneM45 & $30.0(26.6)$ & $20.0(25.4)$ & $30.0(33.0)$ & 1.0 & 10.8 \\
\hline Thrice DithaneM45 & $20.0(31.3)$ & $10.0(11.5)$ & $60.0(51.1)$ & 3.2 & 5.7 \\
\hline Four times DithaneM45 & $40.0(38.9)$ & $53.0(46.2)$ & $0.0(0.6)$ & 1.5 & 7.2 \\
\hline No DithaneM45 x Seradix 3 & $0.0(0.6)$ & $0.0(0.6)$ & $0.0(0.6)$ & 0.0 & 0.0 \\
\hline Once DithaneM45 x Seradix 3 & $20.0(26.1)$ & $20.0(22.1)$ & $0.0(0.6)$ & 3.6 & 3.9 \\
\hline Twice DithaneM45 x Seradix 3 & $50.0(45.0)$ & $50.0(44.7)$ & $20.0(26.1)$ & 5.4 & 12.3 \\
\hline Thrice DithaneM45 x Seradix 3 & $70(57.0)$ & $10.0(15.2)$ & $20.0(25.4)$ & 4.4 & 16.0 \\
\hline Four DithaneM45 x Seradix 3 & $40.0(39.1)$ & $10.0(15.2)$ & $50.0(45.0)$ & 1.7 & 9.4 \\
\hline Interaction LSD $(P=0.05)$ & $(15.6)$ & (ns) & $(14.5)$ & ns & 6.3 \\
\hline
\end{tabular}


Table 4: Degree of infection on shea stem cuttings sprayed with different types of fungicides.

\begin{tabular}{|c|c|c|c|c|}
\hline \multirow{2}{*}{ Fungicide } & \multicolumn{2}{|c|}{ Percentage of dead cuttings } & \multicolumn{2}{|c|}{ Percentage of leaves dropped } \\
\hline & Normal & Infected & Normal & Infected \\
\hline Control & $0.01(0.6)$ & $99.9(89.4)$ & $0.01(0.6)$ & $99.9(89.4)$ \\
\hline Dithane M45 & $0.01(0.6)$ & $6.0(7.3)$ & $28.0(31.4)$ & $5.8(6.5)$ \\
\hline Ridomil Plus & $2.5(6.7)$ & $4.0(4.0)$ & $19.2(25.6)$ & $10.0(17.9)$ \\
\hline Kocide & $2.5(6.7)$ & $5.0(4.5)$ & $21.7(25.8)$ & $11.7(19.6)$ \\
\hline Nordox & $0.01(0.6)$ & $2.5(6.6)$ & $28.6(28.6)$ & $8.8(16.3)$ \\
\hline $\operatorname{LSD}(P=0.05)$ & (ns) & $(4.8)$ & $(9.4)$ & $(10.4)$ \\
\hline \multicolumn{5}{|c|}{ Concentration of Dithane } \\
\hline Control & $0.01(0.6)$ & $99.9(89.4)$ & $0.01(0.6)$ & $99.9(89.4)$ \\
\hline 2000ppm & $5.0(11.8)$ & $2.5(5.7)$ & $19.6(19.6)$ & $20.5(25.8)$ \\
\hline 3000ppm & $5.0(10.7)$ & $4.0(4.0)$ & $10.5(17.9)$ & $6.0(12.2)$ \\
\hline 4000ppm & $6.0(10.5)$ & $0.01(0.6)$ & $5.5(12.7)$ & $6.0(10.6)$ \\
\hline $\operatorname{LSD}(P=0.05)$ & (5.3) & (2.8) & (3.8) & (5.1) \\
\hline \multicolumn{5}{|c|}{$\begin{array}{l}\text { Frequency of application of } \\
2000 \text { ppm Dithane M45 }\end{array}$} \\
\hline Control & $0.01(0.6)$ & $100(89.4)$ & $0.01(0.6)$ & $100.0(89.4)$ \\
\hline Once & $9.0(17.0)$ & $22.4(27.4)$ & $17.0(20.9)$ & $35.0(35.2)$ \\
\hline Twice & $9.8(18.5)$ & $15.5(22.4)$ & $8.0(13.1)$ & $25.0(25.4)$ \\
\hline Thrice & $5.5(12.4)$ & $2.0(5.1)$ & $0.01(0.6)$ & $12.0(13.4)$ \\
\hline Four times & $1.0(3.8)$ & $2.0(5.1)$ & $0.01(0.6)$ & $6.7(8.7)$ \\
\hline $\operatorname{LSD}(P=0.05)$ & $(10.3)$ & $(4.6)$ & (10.4) & $(4.7)$ \\
\hline
\end{tabular}

( ) Figures in parenthesis are angular transformed values

\section{CONCLUSION}

Dithane M45 fungicide is suitable for the control of fungi and also enhances rooting of shea stem cuttings. Dithane M45 at 2000ppm applied once every two weeks and executed three times to the cuttings reduced infection considerably and enhanced rooting. Cuttings which were dipped in Seradix 3 hormone and later sprayed with Dithane M45 showed a remarkable rooting success than the other fungicides. Cuttings sprayed with fungicides only rooted poorly. From this study, it is recommended that shea stem cuttings should be dipped in Seradix 3 hormone and sprayed three times with Dithane M45 at 2000ppm to enhance rooting and control fungal infection. Ridomil 72 Plus, Kocide 101and Nordox 75 lowered rooting performance.

\section{ACKNOWLEDGEMENTS}

We wish to express our thanks to Dr. F. M. Amoah for his advice and motivation during the research and the technical staff at the Cocoa Research Institute of Ghana substation, Bole for assisting in data collection. This paper is published with the permission of the Executive Director of Cocoa Research Institute of Ghana.

\section{REFERENCES}

\section{ns-not significant}

Blazich, F.A., Wright, R.D. and Schauffer, H.E. (1983). Mineral nutrition status of 'Convexa' holly cuttings during intermittent mist propagation as influenced by exogenous auxin application. J. Amer. Soc. Hort. Sci. 109: $350-355$

Dalziel, J.M. (1955). The useful plants of Tropical West Africa. $3^{\text {rd }}$ Edition Crown Agents, London.

Hall, J.B., Aeibisher, D.P., Tomlinson, H.F., Osei-Amaning, E. and Hindle, J.R. (1996). Vitellaria paradoxa, a monograph Project B 4850. Forestry Research Programme. School of Agricultural Science, University of Wales, Banger, U.K, pp 105

Hartmann. H.T., Kester, D.E., Davies. F.T. and Geneve, R.C. (1997). Plant Propagation, principles and practices. Practice hall England, Cliffs, New Jersey 07632. pp 276-391

Irvine, F.R. (1961). Woody plants of Ghana with special reference to their uses. Oxford University Press. London. pp 868

Jackson, J.B. (1986). Development in plants and soil science, new root formation and plants and cuttings. Martinus, Nijhoff Publishers. Dordrecht. pp 149-158, 162-179.

Jarvis, B.C., Yasmin, S., Ali, A.H.M. and Hunt, R. (1984). The interaction between auxin and boron in adventitious root development. The New Phytologist. 97:197-201

Koslowski, T.T. and Kramer, P.J. (1979). Physiology of Woody Plants. $2^{\text {nd }}$ ed. Academic Press. New York. pp. 534-536. 
Landis, T.D., Tinus. R.W. Macdonald, S. E. and Barnett, J. P. (1990). Containers and growing media. The Container Tree Nursery Manual, Vol. 2. Agricultural Handbook, 674, Washington, DC, Forest Services, USDA.

Leopold, A.C. (1960). Auxins and plant growth, 2nd edition, University of California Press. Berkeley and Los Angeles. pp 354

Llewelyn, F.W.M. (1957). The scorching of apple leaves sprayed with copper sulphate. Ann. Appl., Biol., 45:376.

Middleton. W. Jarvis, B.C. and Booth, A. (1980). The role of leaves in auxin and boron dependant on rooting of stem cuttings of Phaseous aureus Roxb. The New Phytologist, 84: 251-259.

Michael, J. and Koffi, L. B. (2001). Shea Butyrospermum paradoxum. Crop production in Tropical Africa. Directorate General for International Co-operation. Ministry of Foreign Affairs, External Trade and International Co-operation, Brussels, Belgium. pp.804808

Moorman, G.W. and Woodbridge, W.C. (1983). Effects of fungicide drenches on root initiation by geranium cuttings. Plant disease. 667, 612-613.

Nanda, K.K. and Tandon, R. (1967). Mechanism of auxin action on rooting of cuttings. Proc. Inter. Symp. Plant
Growth Substances. Calcutta University, Calcutta, pp 250

Ofori-Gyamfi, (1998). Investigation into some factors affecting the vegetative propagation of coffee (Coffea canephora var Robusta, Pierre). M. Phil thesis, Univ. of Cape Coast, Cape Coast, Ghana. pp 173.

Opoku-Ameyaw, (1996). Shea experiments. Report, Cocoa Research Institute of Ghana, Bole Substation, Ghana. 1995/1996. pp 225-228.

Opoku-Ameyaw, K., Amoah, F.M. and Yeboah J. (2000). Studies into the vegetative propagation on the sheanut. J Ghana Sci Assoc. 4(2):138-145.

Otani, H., Haramoto, M., Kohmoto, K. and Nishimura, S. (1985). Two different phases in host cell damages included by AK-toxin of Alternanas alternate Japanese pear pathotype. J Faculty Agric of Yottori University. 20, 8-17.

Reuveni, O. and Raviv, M. (1981). Importance of leaf in relation to rooting of_avocado cuttings. J Amer Soc Hort Sci, 106, 127-130.

Yeboah, J. (2005). Studies into vegetative propagation of the sheanut tree (Vitellaria paradoxa Gaertn) using cuttings. M. Phil thesis, Kwame Nkrumah University of Science and Technology, Kumasi, Ghana. pp 80-82.

Yidana, J.A. (1994). Studies in the sheanut tree. Rep. Cocoa Research Institute of Ghana (1992/1998). pp10. 